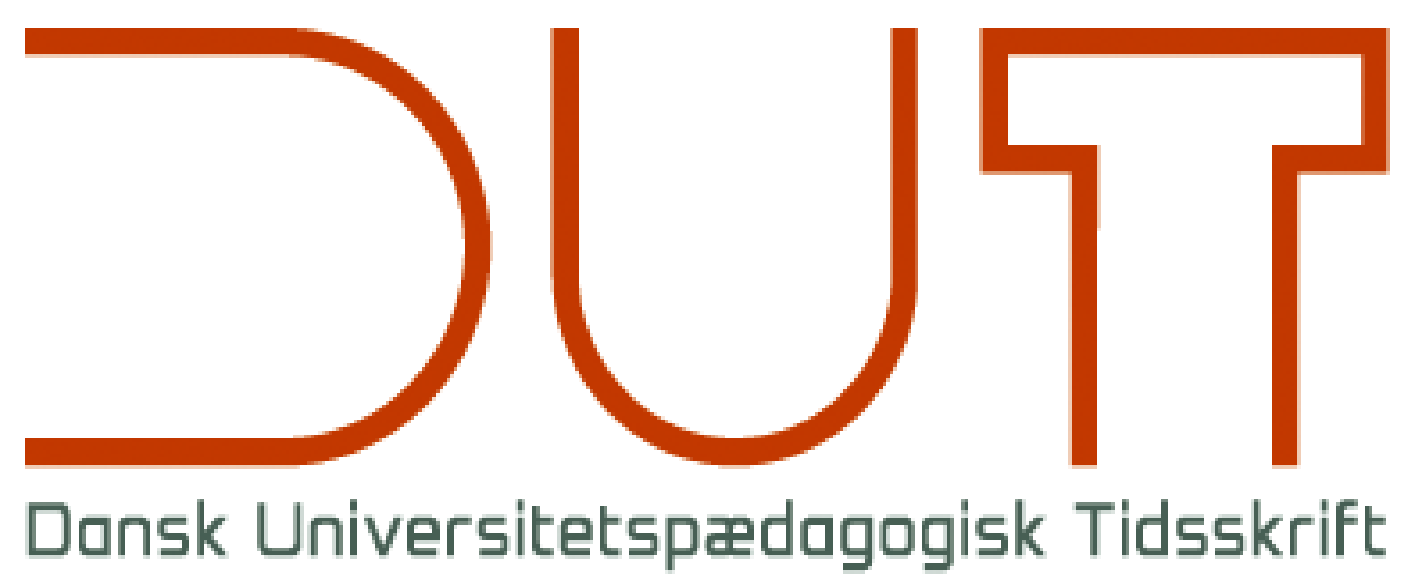

Tema

Autentisk læring

Årgang 15 nr. 29 / 2020

Titel

Et autentisk universitetspædagogisk pusterum

Forfattere

Katrine Lindvig

Sidetal

1

Udgivet af

Dansk Universitetspædagogisk Netværk, DUN

URL

> http://dun-net.dk/

Betingelser for brug af denne artikel

두 Copyright

DUT og artiklens forfatter

Denne artikel er omfattet af ophavsretsloven, og der må citeres fra den. Følgende betingelser skal dog være opfyldt:

- Citatet skal være i overensstemmelse med "god skik"

- Der må kun citeres „i det omfang, som betinges af formålet“

- Ophavsmanden til teksten skal krediteres, og kilden skal angives ift. ovenstående bibliografiske oplysninger. 


\title{
Et autentisk universitetspædagogisk pusterum
}

\author{
Katrine Lindviga, \\ ${ }^{a}$ Ansvarshavende redaktør for Dansk Universitetspædagogisk Tidsskrift, DUT
}

Det er en mærkelig tid. På nogle punkter har vores arbejdsliv og hverdag været sat i stå og på hold - på andre områder føles det, som om det aldrig har gået hurtigere. Aldrig før har vi været så meget 'på' og samtidig så meget alene. Det har for mange været en svær øvelse at være hjemme og til stede i undervisningen samtidig.

Nærværende nummer handler, modsat stort set alt andet lige nu, ikke om corona. Det handler heller ikke om onlineundervisning, nedlukning eller de mange hybride undervisningsrum, som gennem det seneste halve år er blevet hverdag for undervisere og studerende. Alligevel rummer bidragene i DUT 29 erfaringer, pointer og anbefalinger, som også er relevante for den situation, vi pt. befinder os i.

Temaet for dette nummer er nemlig autentisk læring. Begrebet spænder bredt og dækker blandt andet læringssituationer, der afspejler virkelighedens praksis og arbejdsformer, og som evner at skabe engagement og stimulere til refleksion under den faglige såvel som personlige udvikling, som den studerende gennemgår under studiet. Autentiske læringssituationer er derfor også et mål at stræbe efter, selvom undervisningen er rykket til et onlinerum.

Autentiske læringssituationer kan se ud på mange måder: Casebaseret opgaveløsning, rollespil, erhvervspartnerskaber, projektbaseret læring, problembaseret læring og praktikophold er blot nogle af mange bud på universitetspædagogiske tiltag til at fremme overgange fra uddannelse til praksis. Fælles for de fleste tilgange er dog, at de sætter den studerende og dennes erfaring i centrum.

Dette er også en fællesnævner for artiklerne i DUT 29, selvom de indholdsmæssigt er meget forskellige: Fra et fokus på klyngevejledningens muligheder for at understøtte og fremme forskningslignende processer i uddannelsessammenhæng (Hyldegård et al.); rollespil som kobling mellem læringssituationen og den virkelighed, det lærte skal anvendes i (Riemer \& Tofteskov); erfaringer fra pædagogiske interventioner i et matematik kursus (Gynnild \& Tyssedal); scenarieøvelser og transfer i praksisfællesskaber som led i udvikling af en faglig identitet hos den studerende (Nørgaard) - til studerendes blik på overgangen til universitetet (Hansen \& Elving), muligheder og dilemmaer i forskningssamarbejder mellem undervisere og studerende (Hansen et al.) samt problemer, som fylder hos de ph.d.-studerende i starten af studiet, men ikke nødvendigvis bliver til reelle udfordringer senere hen (Kobayashi \& Trolle).

Derudover rummer DUT 29 en håndsrækning til underviserne i form af Jens Dolins guide til studieledere og Donna Hurfords guide til mundtlige eksamener.

Jeg håber, at du som læser vil opleve DUT 29 som værende et autentisk universitetspædagogisk pusterum midt i en coronatid, og at du derudover finder inspiration til at bringe autenticitet ind i din undervisning og vejledning - hvad enten den foregår foran eller gennem en skærm, $\mathrm{i}$ laboratoriet, klasselokalet, sofaen, grupperummet, auditoriet eller i felten.

God læselyst.

${ }^{1}$ Kontakt: katrine.lindvig@ind.ku.dk 